\title{
Climate Risk Impact on Cross-Border Acquisitions
}

\author{
Igor Semenenko \\ Acadia University \\ Junwook Yoo \\ California State University East Bay
}

This article examines impact of climate risks on premium paid in cross-border acquisitions. Results suggest that acquirors from high climate risk geographies tend to offer larger premiums. The results are driven by transactions, in which majority stakes exchange hands, and premium for control is paid to target firm shareholders. There is mild evidence that premiums for control are also higher for targets in low climate risk nations.

Keywords: climate change, climate risk index, cross-border acquisitions, premium for control

\section{INTRODUCTION}

Most of the existing research on climate change focuses on vulnerability of less developed countries to climate-related events (Patt, et. al., 2010), socially responsible investing (Richardson, 2009) or impact of climate changes on specific industries (Dlugolecki, 2008). In addition, Hirshleifer and Shumway (2003) provide a behavioral explanation for impact of sunny weather on stock market returns. This paper aims to establish a direct link between climate risk metrics and cross-border merger activity, connecting two broad strands of literature - on climate change and cross-border acquisitions (M\&A).

I focus on the amount of premium paid by acquirors. My study expands the academic literature on market for corporate control and premium size (Froot and Stein, 1991; Datta and Puja, 1995; Chakrabarti, et. al., 2009; Sonenshine and Reynolds, 2014). Methodologically, this paper is close to Isil, et. al., (2012), who employ Thomson Reuters Securities Data Company (SDC) Platinum database to examine cross-border acquisitions announced between 1990 and 2007.

I observe that acquirors from high climate risk geographies pay larger premiums in cross-border acquisitions controlling for time-varying industry-level latent factors. I find mild evidence that targets in high climate risk areas command lower premiums in acquisitions that result in change in control. These findings are not driven by acquisitions in emerging markets -75 percent of all acquirors are based in the OECD countries, and 49 percent are part of the G7 group. In a similar vein, exclusion of the U.S. market from the sample does not alter main conclusions drawn from this study.

One possible channel through which climate-related events affect premium size is bargaining power of management teams - they may feel pressured to diversify, and larger demand for cross-border targets from the same geographies can tilt balance of supply and demand in favor of the sellers. Adverse events at home could increase pressure to pay additional premiums for target firms. This interpretation could also account 
for relatively small economic impact of climate risks, which may temporarily dislocate supply and demand equilibrium in the market for corporate control. Long-term trends could incorporate climate effects through other channels, including quality of institutions (Acemoglu, et. al., 2001) or directly (Gallup, et. al., 1998).

This study is the first to point out the link between merger activity and climate-related risks. Its advantage lies in use of the climate risk variable that changes from one period to another in contrast to other papers that treat geography as an exogenous factor which has no embedded volatility, thus affecting longterm but not short-term trends.

The organization of the article is as follows. The next section outlines my major hypothesis and provides data description. It is followed by discussion of results, robustness checks and concluding remarks. Appendix provide variables definition.

\section{THE HYPOTHESES, VARIABLES AND SAMPLE DESCRIPTION}

Climate-related events could shift balance of supply and demand in the market for corporate control, implying a positive relationship between acquisition premiums and severity of climate-related events for acquirors, and negative relationship between premiums and climate risks for targets:

$$
\begin{aligned}
& \mathrm{H}_{0} \text { : climate risks are unrelated to deal premiums } \\
& \mathrm{H}_{\mathrm{A}}: \text { climate risk }_{\text {ACQUIROR NATION }} \Rightarrow \text { deal premium } \\
& \text { and climate risk } \\
& \text { TARGET NATION } \Rightarrow \text { deal premium }
\end{aligned}
$$

To control for climate-related risks, I use data on climate risk index (CRI) developed by Germanwatch e.V., a Bonn-based non-government organization, which uses data from the Munich Re reinsurance company and measures impact of extreme weather events and associated socio-economic data. The index takes on low values in high-risk geographies, suggesting a negative relationship between acquiror firms' CRI values and valuation premiums, and a positive relationship between target firms' climate risk proxies and premium size. CRI values are updated annually after 2004, but Germanwatch reports one set of CRI values for 1995-2004 period. Robustness checks confirm that this data limitation does not impact conclusions drawn from this study. Further, empirical data suggests no difference in use of lagged, contemporaneous value or smoothed average of the CRI index. I employ contemporaneous values of climate risk index in regression models, but other results are available upon request.

Valuation premiums relate deal value to target firm assets, controlling for percentage of shares acquired:

premium $/$ discount $=\frac{\text { deal value }_{\text {USD }}}{\text { target assets }{ }_{\text {USD }} \times \%_{\text {ACQUIRED }}}$

Data on mergers and acquisitions are from Thomson Reuters Securities Data Company (SDC) Platinum database. My sample spans 1996-2015 period. Details on sample construction used in this study are outlined below:

Completed acquisitions, excluding self-tender offers

822,003

Cross-border acquisitions

186,676

Completed acquisitions

144,877

Deals with percentage acquired and owned reported not equal to zero $\quad 130,767$

Deals with deal value $(\$ \mathrm{mln})$ and target assets $(\$ \mathrm{mln})$

14,983

Premium/discount metric does not account for net leverage effects - it excludes (debt - cash) correction in the denominator. The omission is intentional because adjustment for net leverage significantly reduces the sample size. To control for omitted variable bias, I include fixed year and industry effects in each 
multivariate model to incorporate leverage effects. Further, I winsorize the premium/discount estimate at 5 percent on each tail to mute outliers' effects. Control variables reported in regression models are summarized in Appendix A.

All regression models employed in this study include fixed year- and industry-effects to account for omitted variable bias - fixed effects subsume industry and industry time-variant latent variables. Forty-eight industries are defined as in Fama and French (1997).

\section{EMPIRICAL RESULTS}

\section{Correlation analysis}

Table 1 reports pairwise correlations for key variables of interest - logarithm of climate risk index (CRI) for target and acquiror nations, valuation premiums and selected control variables. Premiums paid in acquisitions are inversely related to acquiror CRI, suggesting that acquirors in high-risk areas - coded with low CRI values - are willing to pay larger premiums in cross-border mergers. Climate risk index for target firms is also inversely related to premium size, but the variable is less than half the size of the correlation for acquirors.

Correlations on all variables that explain valuation effects are relatively small in absolute terms, and their statistical significance is largely a function of sample size. Yet, all variables have expected signs metrics of economic development and size of the economy as well as governance metrics and exchange rate levels. Tellingly, one of the largest correlations in absolute size is between mortality rates in colonial period and valuation premium. This direct relationship will disappear in multivariate models replicating results of overidentification test in the study on colonial origins of comparative development (Acemoglu, et. al., 2001, table 8).

\section{TABLE 1}

\section{CORRELATIONS FOR SELECTED VARIABLES}

\begin{tabular}{|c|c|c|c|c|c|c|c|c|}
\hline$(1)$ & $(2)$ & (3) & $(4)$ & $(5)$ & $(6)$ & $(7)$ & $(8)$ & $(9)$ \\
\hline $\begin{array}{l}\text { climate } \\
\text { risk }\end{array}$ & gdp & $\begin{array}{l}\text { gdp per } \\
\text { capita }\end{array}$ & population & fx rate & $\begin{array}{c}\text { rule of } \\
\text { law }\end{array}$ & $\begin{array}{c}\text { weighted } \\
\text { distance }\end{array}$ & contiguity & mortality \\
\hline \multicolumn{9}{|c|}{ Panel A. Correlations for acquisitions premium and acquiror nation controls } \\
\hline$-0.09 * * *$ & $0.09 * * *$ & $0.06 * * *$ & $0.07 * * *$ & $0.05 * * *$ & $0.05 * * *$ & $0.08 * * *$ & $-0.03 * * *$ & $-0.03 * * *$ \\
\hline \multicolumn{9}{|c|}{ Panel B. Correlations for acquisitions premium and target nation controls } \\
\hline
\end{tabular}

The table reports pairwise correlations deal premium, climate risk measures for targets and acquirors, and selected control variables. Data in columns $1,2,3,4$ and 7 is in logs. ${ }^{* * *}$ and ${ }^{* * *}$ indicate a p-value of $10 \%, 5 \%$, and $1 \%$, respectively.

\section{Valuation Premiums and Climate Risks}

I employ generalized least squares (GLS) estimation to examine relationship between climate-related events and valuation premiums to correct for heteroskedasticity and possible correlation between model residuals.

A clear pattern emerges from models reported in table 2 - acquiring firms in high-risk areas overpay for acquisitions. Models in panels C-D incorporate the same covariates as panel A models and include categorical variables that represent 5 and 10 percent on the left tail of the climate risk curve point in the same direction. In addition, they allow us to fine-tune results in models that include a continuous climate risk variable.

It follows that results are driven by the bottom 10 percent of the observations. Note that absolute value of 10 percent categorical variable in panel $\mathrm{C}$ is the same as logarithm of climate risk measure in panel A. Further, effects are clearly non-linear - five percent categorical variable in panel D attains point estimates that are almost twice the size of values for the ten percent variable in panel C. Further, goodness-of-fit of 
models with a five percent categorical variable is higher than in models with a 10-percent dummy or continuous risk proxy metric.

Results for target firms are indeterminate. The primary variable of interest - logarithm of target CRI is not significant in any of the specifications in panels B, E and F of table 2, suggesting that investors do not offer lower premiums for firms in high-risk geographies. Categorical variables models in panels E-F include the same covariates as models in panel B with continuous measure of risk.

In summary, I find partial support for my overpayment hypothesis - acquirors from high climate risk areas are willing to offer a higher cross-border valuation premium; yet, there is no evidence that targets in high risk areas command lower premiums.

TABLE 2

REGRESSIONS WITH DEAL PREMIUM AS DEPENDENT VARIABLE

\begin{tabular}{|c|c|c|c|c|c|c|}
\hline & $(1)$ & $(2)$ & $(3)$ & $(4)$ & $(5)$ & $(6)$ \\
\hline \multicolumn{7}{|c|}{ Panel A. Regression models with acquiror nation logarithm of CRI } \\
\hline \multirow[t]{2}{*}{ acquiror cri (log) } & $-0.25^{* * *}$ & $-0.20 * * *$ & $-0.22 * * *$ & $-0.17 * * *$ & $-0.23 * *$ & $-0.19 * * *$ \\
\hline & 0.04 & 0.04 & 0.04 & 0.04 & 0.05 & 0.06 \\
\hline \multirow[t]{2}{*}{ acquiror gdp $(\log )$} & & 0.01 & & $0.03 *$ & & \\
\hline & & 0.02 & & 0.02 & & \\
\hline \multirow[t]{2}{*}{ acquiror population $(\log )$} & & & 0.02 & & & \\
\hline & & & 0.02 & & & \\
\hline \multirow[t]{2}{*}{ acquiror gdp per capita $(\log )$} & & $0.15^{* * *}$ & $0.16^{* * *}$ & & & \\
\hline & & 0.02 & 0.04 & & & \\
\hline \multirow[t]{2}{*}{ acquiror fx rate } & & & & $0.28 * * *$ & -0.06 & 0.24 \\
\hline & & & & 0.09 & 0.11 & 0.19 \\
\hline \multirow[t]{2}{*}{ acquiror rule of law } & & & & & $1.01 * * *$ & $0.81^{*}$ \\
\hline & & & & & 0.27 & 0.40 \\
\hline \multirow[t]{2}{*}{ weighted distance (log, mean) } & & $0.07 * * *$ & & & $0.08 * * *$ & $0.07^{* *}$ \\
\hline & & 0.02 & & & 0.02 & 0.03 \\
\hline \multirow[t]{2}{*}{ common border } & & & $-0.15 * * *$ & $-0.15 * * *$ & & \\
\hline & & & 0.04 & 0.04 & & \\
\hline \multirow[t]{2}{*}{ acquiror mortality (log) } & & & & & & 0.04 \\
\hline & & & & & & 0.05 \\
\hline N. of observations & 14,102 & 12,981 & 12,981 & 12,937 & 12,404 & 7,807 \\
\hline R-square & 0.120 & 0.127 & 0.127 & 0.125 & 0.129 & 0.123 \\
\hline \multicolumn{7}{|c|}{ Panel B. Regression models with target nation logarithm of CRI } \\
\hline \multirow{2}{*}{ target cri $(\log )$} & -0.06 & 0.07 & 0.06 & 0.05 & -0.04 & -0.05 \\
\hline & 0.04 & 0.09 & 0.09 & 0.08 & 0.06 & 0.08 \\
\hline \multirow[t]{2}{*}{ target gdp $(\log )$} & & $0.07 * *$ & & $0.08 * *$ & & \\
\hline & & 0.03 & & 0.03 & & \\
\hline \multirow[t]{2}{*}{ target population $(\log )$} & & & $0.08 * *$ & & & \\
\hline & & & 0.03 & & & \\
\hline \multirow[t]{2}{*}{ target gdp per capita $(\log )$} & & 0.02 & $0.09 * * *$ & & & \\
\hline & & 0.03 & 0.02 & & & \\
\hline \multirow[t]{2}{*}{ target $\mathrm{fx}$ rate } & & & & 0.05 & -0.02 & 0.12 \\
\hline & & & & 0.08 & 0.16 & 0.21 \\
\hline \multirow[t]{2}{*}{ target rule of law } & & & & & $0.65^{*}$ & -0.71 \\
\hline & & & & & 0.37 & 0.42 \\
\hline \multirow[t]{2}{*}{ weighted distance (log, mean) } & & $0.09 * * *$ & & & $0.11 * * *$ & $0.15 * * *$ \\
\hline & & 0.02 & & & 0.02 & 0.02 \\
\hline
\end{tabular}




\begin{tabular}{lll}
\hline common border & $-0.15^{* * *}$ & $-0.15^{* * *}$ \\
& 0.04 & 0.04
\end{tabular}

target mortality $(\log )$

\begin{tabular}{|c|c|c|c|c|c|}
\hline & & & & & $\begin{array}{l}-0.19 * * * \\
0.05\end{array}$ \\
\hline 4,873 & 13,675 & 13,675 & 13,571 & 12,904 & 8,875 \\
\hline 116 & 0.122 & 0.121 & 0.120 & 0.122 & 0.124 \\
\hline
\end{tabular}

N. of observations

$0.116 \quad 0.122$

0.121

0.120

0.122

Panel C. Betas on 10 percent high-risk categorical variable for acquiror nations

$\begin{array}{lllllll}\text { acquiror } 10 \text { percent dummy } & 0.27^{* * *} & 0.19^{* *} & 0.20^{* *} & 0.18^{* *} & 0.25^{* * *} & 0.18^{*} \\ & 0.09 & 0.07 & 0.08 & 0.08 & 0.08 & 0.10\end{array}$

Panel D. Betas on 5 percent high-risk categorical variable for acquiror nations

$\begin{array}{lllllll}\text { acquiror } 5 \text { percent dummy } & 0.46^{* * *} & 0.30^{* *} & 0.32^{* *} & 0.32^{* *} & 0.37^{* *} & 0.32^{* *} \\ & 0.13 & 0.13 & 0.12 & 0.13 & 0.13 & 0.14\end{array}$

Panel E. Betas on 10 percent high-risk categorical variable for target nations

$\begin{array}{lllllll}\text { target } 10 \text { percent dummy } & -0.00 & -0.09 & -0.09 & -0.09 & -0.03 & -0.03 \\ & 0.06 & 0.08 & 0.08 & 0.07 & 0.06 & 0.08\end{array}$

Panel F. Betas on 5 percent high-risk categorical variable for target nations

\begin{tabular}{lllllll} 
target 5 percent dummy & -0.08 & -0.15 & -0.13 & -0.14 & -0.09 & -0.05 \\
& 0.07 & 0.10 & 0.09 & 0.08 & 0.07 & 0.08 \\
\hline
\end{tabular}

This table reports regression model results with deal value over asset of the target firm as dependent variable. Deal value ratio is winsorized at 5 percent level. Climate risk variable is specified as a natural logarithm of climate risk index (CRI) in panels A-B and as a categorical variable in panels C-D. A total of 2,716 acquirors and 2,523 targets are coded as 10 percent high climate risk; 1,152 acquirors and 1,028 targets are coded as 5 percent high climate risk. All models include fixed year and industry effects. Intercepts and categorical variables representing 48 industries and year effects are omitted. Sample includes 14,983 cross-border acquisitions. ${ }^{*}, * *$ and $* * *$ indicate a p-value of $10 \%$, $5 \%$, and $1 \%$, respectively.

\section{Premium for Control}

Next, I test whether deal premiums are invariant to size of the acquired stake in the target firm. Table 3 reports results for 8,313 transactions, in which a majority stake - more than 50 percent - exchanged hands.

The results for control-changing acquisitions are stronger than for the whole sample. Not only are climate risk variables more significant for acquiror firms, but the variables of interest - logarithm of climate risk metric and both categorical variables - attain statistical significance and expected signs. Interestingly, climate risk variable attains significance and expected signs in three models in panel B, which employs continuous measure of risk, and three models in panel F, which include five percent categorical variable. As before, lower values of continuous measure of risk correspond to higher climate risk. Categorical variables that proxy for climate risk should therefore obtain signs opposite to corresponding continuous metrics. 


\section{TABLE 3 \\ CLIMATE RISK VARIABLES BETAS FOR MAJORITY STAKES IN MODELS WITH DEAL PREMIUM}

\begin{tabular}{|c|c|c|c|c|c|c|}
\hline & $(1)$ & $(2)$ & $(3)$ & $(4)$ & $(5)$ & $(6)$ \\
\hline \multicolumn{7}{|c|}{ Panel A. Betas of acquiror nation logarithm of CRI } \\
\hline acquiror cri (log) & $-0.31 * * *$ & $-0.25 * *$ & $-0.28 * *$ & $-0.21 * * *$ & $-0.30 * * *$ & $-0.24 * * *$ \\
\hline \multicolumn{7}{|c|}{ Panel B. Betas of target nation logarithm of CRI } \\
\hline target cri $(\log )$ & -0.02 & $0.22 * *$ & $0.21^{* *}$ & $0.18^{* *}$ & 0.02 & -0.01 \\
\hline \multicolumn{7}{|c|}{ Panel C. Betas of 10 percent high-risk categorical variable for acquiror nations } \\
\hline acquiror 10 percent dummy & $0.31 * * *$ & $0.23^{* *}$ & $0.24 * *$ & $0.21 * *$ & $0.31 * * *$ & $0.25 * * *$ \\
\hline \multicolumn{7}{|c|}{ Panel D. Betas of 5 percent high-risk categorical variable for acquiror nations } \\
\hline acquiror 5 percent dummy & $0.52 * * *$ & $0.37 * * *$ & $0.40 * * *$ & $0.40 * * *$ & $0.44 * * *$ & $0.32 * * *$ \\
\hline \multicolumn{7}{|c|}{ Panel E. Betas of 10 percent high-risk categorical variable for target nations } \\
\hline target 10 percent dummy & -0.03 & -0.13 & -0.13 & -0.12 & -0.05 & -0.04 \\
\hline \multicolumn{7}{|c|}{ Panel F. Betas of 5 percent high-risk categorical variable for target nations } \\
\hline target 5 percent dummy & $-0.12 * *$ & $-0.26 * *$ & $-0.24 * *$ & $-0.22 * *$ & $-0.14^{*}$ & -0.12 \\
\hline
\end{tabular}

This table reports betas for regression models for transactions, in which majority stakes - over 50 percent - exchange hands. Sub-sample includes 8,313 observations. Models specification is identical to table $2 . * * *$ and $* * *$ indicate a p-value of $10 \%, 5 \%$, and $1 \%$, respectively.

Table 4 summarizes the results for 6,670 transactions with minority stakes. Results fall in line with earlier findings - premiums on minority stakes are unrelated to higher level of climate risk either for acquirors or targets. Clearly, my results are driven by larger premiums for control reported in table 3 .

TABLE 4

\section{CLIMATE RISK BETAS FOR MINORITY STAKES IN MODELS WITH DEAL PREMIUM}

\begin{tabular}{|c|c|c|c|c|c|c|}
\hline & (1) & (2) & (3) & (4) & (5) & (6) \\
\hline \multicolumn{7}{|l|}{ Panel A. Betas of acquiror nation logarithm of CRI } \\
\hline acquiror cri $(\log )$ & $-0.17 * * *$ & -0.11 & -0.13 & -0.11 & $-0.12 *$ & -0.08 \\
\hline \multicolumn{7}{|l|}{ Panel B. Betas of target nation logarithm of CRI } \\
\hline target cri $(\log )$ & $-0.14 * * *$ & 0.10 & -0.11 & -0.09 & -0.12 & -0.11 \\
\hline \multicolumn{7}{|c|}{ Panel C. Betas of 10 percent high-risk categorical variable for acquiror nations } \\
\hline acquiror 10 percent dummy & 0.19 & 0.12 & 0.12 & 0.12 & 0.14 & 0.04 \\
\hline \multicolumn{7}{|c|}{ Panel D. Betas of 5 percent high-risk categorical variable for acquiror nations } \\
\hline acquiror 5 percent dummy & 0.33 & 0.16 & 0.18 & 0.18 & 0.21 & 0.26 \\
\hline \multicolumn{7}{|c|}{ Panel E. Betas of 10 percent high-risk categorical variable for target nations } \\
\hline target 10 percent dummy & 0.07 & -0.04 & -0.04 & -0.05 & 0.01 & -0.00 \\
\hline \multicolumn{7}{|c|}{ Panel F. Betas of 5 percent high-risk categorical variable for target nations } \\
\hline target 5 percent dummy & 0.03 & -0.00 & 0.01 & -0.01 & 0.02 & 0.07 \\
\hline
\end{tabular}

This table reports betas for regression models for transactions, in which minority stakes - less than or equal to 50 percent - exchange hands. Sub-sample includes 6,670 observations. Models specification is identical to models in table $2 . * * *$ and $* * *$ indicate a p-value of $10 \%, 5 \%$, and $1 \%$, respectively.

\section{Robustness Checks}

A significant number of acquisitions in my sample involves developed countries which have experienced adverse climate-related events. It is possible that climate risk index captures some of the characteristics of the developed nations, acting as a proxy for country characteristics unrelated to climate change. To rule out this possibility, I eliminated all G7 acquirors, leaving 8,073 acquiring firms from nonG7 nations. 
Results in table 5 are weaker, but they do not lead to different conclusions - acquirors with low climate risk scoring pay larger premiums. Interestingly, categorical variables experience the largest change, suggesting that premiums distribution in the non-G7 acquirors' subsample is less concentrated in the left tail of the distribution than in the subsample of the G7 acquirors.

Another possibility is for climate risk variables to capture growth opportunities. Countries with high level of climate risk could have lower growth rates, so regression models tested in this study could suffer from omitted variable bias. To address this concern, I added growth rates for acquiror and target nations using average of growth rates in real gross domestic product in the three years preceding the merger event to proxy for future growth rates. I incorporated these two variables interchangeably in all specifications and re-visited the results. Neither of these variables affects significance of betas on climate risk variables or changed goodness-of-fit of regression models (results available upon request).

\section{TABLE 5 \\ CLIMATE RISK VARIABLES BETAS IN MODELS WITH DEAL PREMIUM WITHOUT G7 NATIONS}

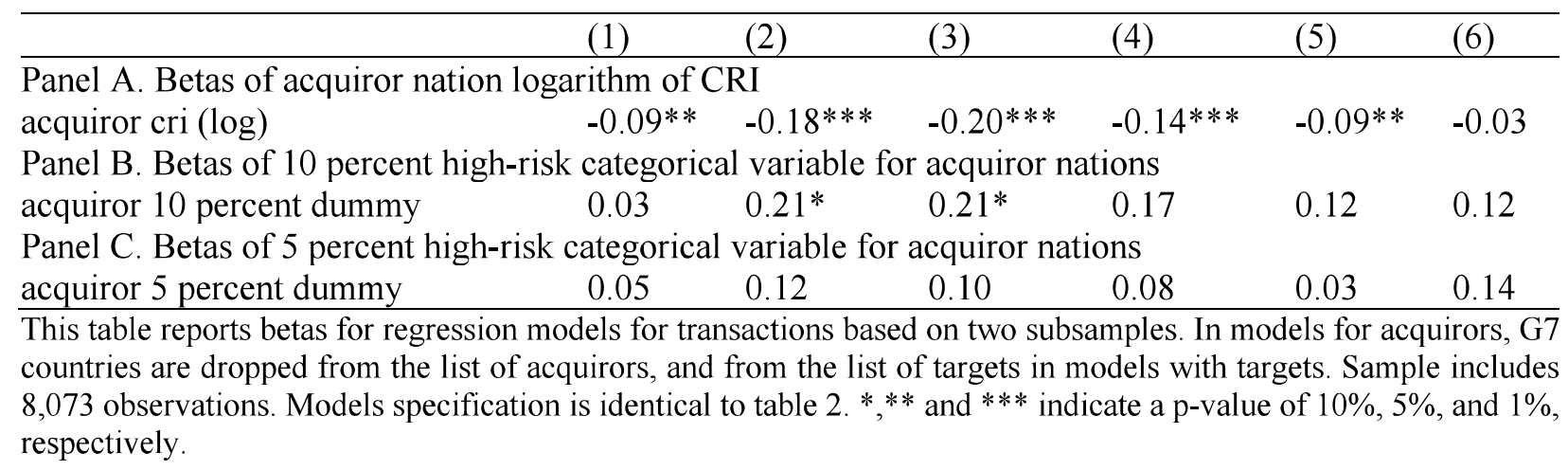

Following Acemoglu, et. al., (2001), I test whether settler mortality could be used as an instrumental variable to model climate risk proxy in a two-stage least squares specification. However, my climate risk metric is positively correlated with mortality rates, and R-squared in the first stage model is just a fraction of one percentage point. Tellingly, settler mortality does not attain significance in any of the specifications for acquiror firms, and this variable does not improve models' goodness-of-fit (see model 6 in panels A-E). This suggests that settler mortality effect operates through other channels and that it is accounted for by other variables included in the model specification.

Finally, I examined whether acquisition premiums could be industry-clustered, using KPMG Survey of Corporate Responsibility Reporting 2017 to identify forestry \& paper, chemicals, mining, oil \& gas, automotive and utilities as high-risk industries (KPMG, 2017). My results suggested economy-wide rather than industry-specific effects. Alternatively, existing research may have failed to come up with a proper way to identify industries at risk.

\section{CONCLUSION}

My paper uncovers a link between cross-border merger activities and climate-related risks. Acquirors in high-risk geographies pay higher premiums for control compared to firms located in less affected areas. Further, I document mild evidence that targets in high-risk geographies command lower premiums.

Premium size is not unique to industries that had the highest rate of acknowledging climate-related risk in a study undertaken by the KPMG (KPMG, 2017), suggesting broad economy-wide effects on climate change. Finally, relationship between climate-related events and premium paid by acquirors is robust to controlling for growth prospects and exclusion of the most developed nations from the study. 
Results of this study have implications for management teams of acquisitive firms in high-risk climate zones. One possible channel through which climate risks could affect valuation premiums is by effect on the bargaining power of negotiating teams - managers of acquiring firms could feel stronger sense of urgency in the face of adverse exogenous shocks.

\section{REFERENCES}

Acemoglu, D., Johnson, S., \& Robinson, J.A. (2001). The colonial origins of comparative development: an empirical investigation. The American Economic Review, 91(5), 1369-1401.

Chakrabarti, R., Gupta-Mukherjee, S., \& Jayaraman, N. (2009). Mars-Venus marriages: culture and crossborder M\&A. Journal of International Business Studies, 40(2), 216-236.

Datta, D.K., \& Puia, G. (1995). Cross-border acquisitions: an examination of the influence of relatedness and cultural fit on shareholder value creation in U.S. acquiring firms. MIR: Management International Review, 35(4), 337-359.

Dlugolecki, A. (2008). Climate change and the insurance sector. The Geneva Papers on Risk and Insurance. Issues and Practice, 33(1), 71-90.

Isil, E., Liao, R.C., \& Weisbach, M.S. (2012). Determinants of cross-border mergers and acquisitions. The Journal of Finance, 67(3), 1045-1082.

Fama, E.F., \& French, K.R. (1997). Industry costs of equity. Journal of Financial Economics, 43(2), 153193.

Froot, K.A., \& Stein, J. (1991). Exchange rates and foreign direct investment: an imperfect capital market approach. Quarterly Journal of Economics, 106(4), 1191-1217.

Gallup, J.L., Mellinger, A.D., \& Sachs, J.D. (1998). Geography and economic development. National Bureau of Economic Research. Working Paper No. 6849.

Hirshleifer, D., \& Shumway, T. (2003). Good Day Sunshine: Stock Returns and the Weather. The Journal of Finance, 58(3), 1009-1032.

KPMG Survey of Corporate Responsibility Reporting 2017. (2017). The road ahead.

Patt, A.G., Tadross, M., Nussbaumer, P., Asante, K., Metzger, M., Rafael, J., . . Schneider, S.H. (2010). Estimating least-developed countries' vulnerability to climate-related extreme events over the next 50 years. Proceedings of the National Academy of Sciences of the United States of America, 107(4), 1333-1337.

Richardson, B.J. (2009). Climate finance and its governance: moving to a low carbon economy through socially Responsible Financing. The International and Comparative Law Quarterly, 58(3), $597-$ 626.

Sonenshine, R., \& Reynolds, K. (2014). Determinants of cross-border merger premia. Review of World Economics / Weltwirtschaftliches Archiv, 150(1), 173-189. 


\section{APPENDIX A \\ DESCRIPTION OF VARIABLES}

The appendix reports variables used to describe various characteristics of acquiror- and target-nations.

acquiror/target population (log)

acquiror/target gdp per capita $(\log )$

Source: World Bank

acquiror/target $\mathrm{fx}$ rate

acquiror/target rule of law

weighted distance $(\log$, mean) logarithm of population in millions. Source: World Bank

logarithm of GDP per capita at purchasing power parity in USD.

real effective exchange rate relative to the U.S. dollar. Source:

World Bank

rule of law percentile rank. Source: World Bank

natural logarithm of equally-weighted distance (distw) between acquiror and target nations. Source: GEODIST database, CEPII

common border categorical variable equal to one if acquiror and target nations share a common border.

Source: GEODIST database, CEPII

acquiror/target mortality $(\log )$

logarithm of a settler mortality per 1,000 per annum. Source:

Daron Acemoglu, MIT Economics 